\title{
THE SOUTH AFRICAN COAL MINING INDUSTRY: A NEED FOR A MORE EFFICIENT AND COLLABORATIVE SUPPLY CHAIN
}

\author{
DAVID POOE \\ KENNETH MATHU \\ pooe@vut.ac.za \\ Department of Logistics \\ Vaal University of Technology
}

\begin{abstract}
It is estimated that about two-thirds of global coal is used for power generation and that, in the next 20 years, over $70 \%$ of the demand for coal will come from China and India. Coal accounts for approximately $41 \%$ of the world's electricity generation. Demand for thermal coal is influenced by factors that include availability, prices of competing products such as oil, gas and nuclear power, and the demand for electricity. The aim of this article is to provide an exposition of supply chain dynamics within the South African coal mining industry and to argue for a more efficient and collaborative supply chain. The authors attempt to investigate at local and global level, the current trends pertaining to the level of reserves, production and consumption of coal. The article further demonstrates the shortcomings of current logistics in meeting the demand for coal in both domestic and export markets. The article draws from secondary data sourced from academic papers, government and agency documents in the exposition of the coal mining supply chain. The paper concludes by recommending the need for a scientific study on supply chain constraints facing the coal mining industry in South Africa.
\end{abstract}

\section{INTRODUCTION}

Since the last quarter of 2007 South Africa has been experiencing a shortage of electrical power (Nersa, 2008:38). Eskom Holdings is the sole distributor of electrical power in South Africa. The resultant power outages adversely affected the whole country, and the mining sector was forced to operate at $10 \%$ below capacity in an effort to conserve power. Through the National Energy Regulator of South Africa (Nersa), the government initiated an investigation into the entire electricity crisis. The investigation revealed that the problem could be mainly attributed to poor planning in the coal mining industry (Nersa, 2008:38). However, Nyanjowa (2009:8) offers a different perspective, arguing that South Africa's coal mining industry remains unbalanced, with rising coal demand on the one hand and constrained supply sources on the other. Nyanjowa (2009:8) adds that the South African coal mining industry needs to position itself well in order to meet the increased demand for coal in domestic and international markets. 
Part of the challenge experienced by the South African coal mining industry is aptly captured by the following excerpt from the Department of Transport (2005:14):The freight system in South Africa is fraught with inefficiencies at system and firm levels. There are infrastructure shortfalls and mismatches; the institutional structure of the freight system is inappropriate, and there is lack of integrated planning. Information gaps and asymmetries abound; the skills base is deficient, and the regulatory frameworks are incapable of resolving problems in the industry.

This study seeks to address some of these challenges by demonstrating the need for a more efficient and collaborative supply chain within the South African coal mining industry. In this regard, Furter (2005:13) suggests that improving collaboration in the supply chain enhances responsiveness and flexibility. As such, companies can gain competitive advantages through implementing strategies that allow for collaboration, integration, and the sharing of information needs. The need for an efficient and a more collaborative supply chain in the coal industry is accentuated by the extensive capital investments that are currently being implemented. These include the Eskom Development Programme which will require the establishment of an additional 40 coal mines, Transnet Rail Expansion Programme, the expansion of the Richards Bay Coal Terminal (RBCT), and the introduction of independent power producers, and Sasol's capacity expansion, among others.

\section{SOUTH AFRICA'S COAL RESERVES, PRODUCTION AND EXPORT}

Coal is an important energy source which contributes approximately $41 \%$ of total world electricity generation (Smuts, 2010:16). By 2009 coal remained the fastest-growing fuel in the world for a sixth consecutive year (BP, 2009:5). Coal presently fuels about 39\% of the world's electricity and about $56 \%$ of the global consumption is in Asia (Abbott, Apostolik, Goodman, Jenner, Labhart, Maragos, May, Sunderman, Parker, Stein, Wengler \& Went [GARP], 2009:56). The Department of Mineral Resources (DMR 2009:44) discloses that countries export only $16 \%$ of the global coal production, while the rest is consumed in domestic markets. Due to its use as a fuel for the generation of electricity and other commercial purposes in the world, coal is a highly traded commodity. Molteno (2008:189) underscores that, in addition to being the primary source of electricity in South Africa, coal also provides the country with a third of its liquid fuel requirements.

According to the DMR (2009:44), global recoverable reserves of coal are estimated at 411321 million tonnes (Mt). The top six nations which possess the largest coal reserves are the United States, with reserves of $108950 \mathrm{Mt}$, followed by China (62 $200 \mathrm{Mt}$ ), India (54 $000 \mathrm{Mt}$ ), Russia (49 $088 \mathrm{Mt}$ ), Australia (36 $800 \mathrm{Mt}$ ) and South Africa (30 $408 \mathrm{Mt}$ ) (DMR 2009:44). Lok (2009:22) estimates that at the current rate of consumption, world coal reserves may last only another 150 years. Venables (2008:48) proposes that at current rates of production there are enough coal reserves to last the world another 130 years. 
According to Hartnady (2011:23), commercial mining of coal in South Africa commenced in the 1880s. Cumulatively, 6.982 billion tonnes of coal were produced between 1885 and 2006 (DMR, 2009:52). By 2007, there were 73 collieries in South Africa which were distributed per province as follows: Mpumalanga (61), KwaZulu-Natal (7), Free State (2), Limpopo (2), and Gauteng (1) (DME, 2007:44). The leading coalfields in Mpumalanga are in Emalahleni and Highveld (Prevost, 2009:6).

The Chamber of Mines (2009:25) reports that the world's proven total anthracite, bituminous, sub-bituminous and lignite coal reserves have fallen from 847.5 billion tonnes in 2007 to 826 billion tonnes in 2009 while coal reserves in South Africa were estimated at $30408 \mathrm{Mt}$ in 2008. World coal production in 2007 reflected an increase of $38 \%$ in the last 20 years. Abbott, et al. (GARP) (2009:54) attribute this increase in production to the increased demand for energy which triggered a faster growth of the Asian economy. Chadwick (1994:154) argues that although coal may gradually lose its share of the energy market overall, demand will grow slightly, notwithstanding the extra costs of environmental compliance.

Smuts (2008:33) predicts that over 70\% of the demand for coal in the next 20 years will come from China and India, which is notable since 2003 official estimates for South Africa have dramatically reduced its coal reserves (BP, 2009; Hartnady, 2010:1). Since then, coal production has remained fairly stagnant, which is attributable to depleted coal mines in the Emalahleni, Ermelo and Highveld coalfields in Mpumalanga, as well as operational and technological constraints (Wood, 2010:1). Yet, during the same period, consumption by Eskom has risen to meet power demand (Smuts, 2008:33). This situation has created competition between Eskom and other domestic consumers of coal. Consequently, coal prices have risen, forcing Eskom to wash and reuse coal that would have been discarded by coal exporters. Smuts (2008:36) reiterates that demand will continue to outstrip supply for some time until new coal mines come on stream.

Over $80 \%$ of saleable coal production in South Africa is supplied by mines controlled by the largest five mining groups, namely: Anglo Coal, BHP Billiton, Exxaro, Sasol and Xstrata, while the remainder is produced by smaller mines (junior miners) that have Black Economic Empowerment (BEE) partners (Mining Weekly, 2010:1). About 75\% of the coal produced in South Africa is used locally, mainly for electricity generation by Eskom power plants and for liquid fuels by Sasol (DMR, 2009). In 2008, the South African coal market was estimated to be 252.2 Mt comprising 194.3 Mt for domestic market and 57.9 Mt for export (DMR, 2009). 
Graph 1 illustrates South African coal market distribution in 2009.

\section{South African Coal Market Distribution in tons, 2009}

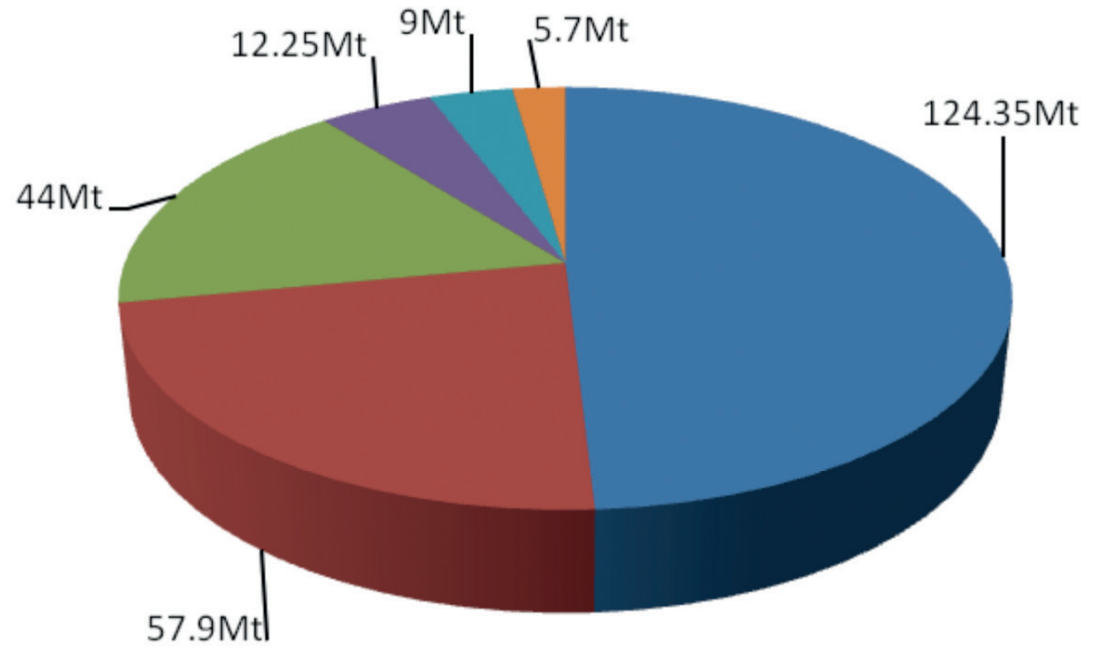

Electricity generator (Eskom)

(124.35Mt)

- Export (57.9Mt)

- Synthetic fuels (Sasol) (44Mt)

- Merchants (12.25Mt)

Industries (9Mt)

netallurgical (5.7Mt)

Graph 1: South African coal market distribution in tonnes, 2009 Source: (DMR, 2009:48)

It is estimated that in the next decade, while South Africa will increase annual coal production by $75 \mathrm{Mt}$, at some point coal production will stagnate and will not be able to meet the energy demand (Lok, 2009:22). Hartnady (2011:27) contends that this is mainly due to lack of reinvestment by the main producers to the extent that most of the large collieries with an output of $10 \mathrm{Mt}$ per year will are likely to close down or their reserves will be near exhaustion by the year 2020. Nevertheless, Eskom's coal consumption has not changed much in the last ten years, which is one of the reasons the country has been experiencing power shortages. Notably, no large power plants were built during that period. The two new coal-fired power plants, namely Medupe and Kusile, will only come on stream around the year 2013 (Eskom, 2009:59). Table 1 shows the coal consumption by Eskom coal-fired power plants for 12 years commencing in 1999 and terminating in 2010. 
Table 1: Coal consumption by Eskom (1999-2010)

Source: Eskom (2010)

\begin{tabular}{|c|c|}
\hline Year & Million tonnes (Mt) \\
\hline 1999 & 94.86 \\
\hline 2000 & 95.19 \\
\hline 2001 & 91.73 \\
\hline 2002 & 92.62 \\
\hline 2003 & 104.08 \\
\hline 2004 & 110.98 \\
\hline 2005 & 106.30 \\
\hline 2006 & 108.75 \\
\hline 2007 & 112.17 \\
\hline 2008 & 125.30 \\
\hline 2009 & 121.16 \\
\hline 2010 & 122.70 \\
\hline
\end{tabular}

Table 1 reflects almost uniform coal consumption rates in the 1999-2002 period. Consumption increased slightly from 2003 to 2006 . The period from 2007 marks the beginning of a steep increase in consumption from 112.17 Mt in 2007 to $125.30 \mathrm{Mt}$ in 2008. This was the period when the country started experiencing power black-outs, which has changed the complexion of the demand for power in South Africa, as massive tariff hikes have been implemented to meet projected power supply capacities in the future. Then in 2009 there was a decrease in the consumption of coal thanks to the global economic slowdown. The year 2010 experienced a slight increase in the consumption of coal by Eskom.

\section{COAL LOGISTICS IN SOUTH AFRICA}

A survey by the Council for Scientific and Industrial Research (CSIR) (2006) shows that the support rendered to South African businesses by the national logistics infrastructure is inadequate. According to Furter (2005:13) there is a need for increased flexibility and responsiveness since South Africa is geographically located away from its major international markets and its exports constitute about $30 \%$ of the gross domestic product (GDP). Total logistics costs are around $14.5 \%$ of the GDP, relatively higher than its trading partners such as the USA where logistics costs stand at about 9.9\% of the GDP for 2006 (Van Dyk, Ittmann, Marais, Meyer \& Maspero, 2008:93). The following section looks at some of the major participants in the logistics of the SA coal mining industry.

\section{The role of Transnet}

Transnet's business unit, Transnet Freight Rail (TFR), is responsible for rail freight. The main focus of TFR is transporting bulk and containerised freight. During the 2007/2008 period, the division transported 179.9 Mt of freight for export and domestic customers (Transnet, 
2008:10). This figure went down to about 177 Mt between 2008 and 2009 (Transnet, 2009:2). The total coal transported in 2008 was 67 Mt (Transnet, 2008:97). Other coal shipments by Transnet were 71.4 Mt in 2005, 68.7 Mt in 2006 and 67.7 Mt in 2007 (DMR, 2009: 46). Table 2 shows Transnet coal shipment for six years, extending from 2005 to 2010.

Table 2: Coal shipment by Transnet 2005-2008

Source: Compiled from various sources

\begin{tabular}{|c|c|}
\hline Year & Freight (Mt) \\
\hline 2005 & 71.4 \\
\hline 2006 & 68.7 \\
\hline 2007 & 67.7 \\
\hline 2008 & 67.0 \\
\hline 2009 & 61.0 \\
\hline 2010 & 62.9 \\
\hline
\end{tabular}

Table 2 shows a decline in coal shipments by Transnet between 2005 and 2008. According to Prevost (2009:17) coal exports in 2009 slumped to 61.1 Mt per annum (Mtpa) as a result of Transnet's decreased capacity which was below that of Richards Bay Coal Terminal (RBCT). However, Transnet has belatedly launched the 'Quantum Leap Project' to raise rail capacity to 81 Mtpa while plans are already underway for the 'Beyond 81 Mtpa Project'. This positive development was motivated by the prediction that India is expected to import $110 \mathrm{Mt}$ of coal from 2012, of which 25 Mt will come from South Africa. Table 3 shows the monthly coal shipments by TFR year-to-date (YTD) March 2010 to February 2011.

Table 3: Transnet Freight Rail's (TFR) Operating Statistics, 2010/2011

Source: South African Coal Report (2011:8)

\begin{tabular}{|l|c|c|c|c|}
\hline Date & TFR railings (Mt) & YTD (Mt) & Annualised rate (Mtpa) & Number of trains \\
\hline Mar 2010 & 5.9 & 15.6 & 66.8 & $\mathbf{8 1 1}$ \\
\hline Apr 2010 & 5.6 & 21.2 & 67.1 & $\mathbf{7 5 5}$ \\
\hline May 2010 & 1.9 & 23.1 & 58.0 & $\mathbf{2 0 1}$ \\
\hline Jun 2010 & 5.2 & 28.3 & 58.7 & $\mathbf{6 3 8}$ \\
\hline Jul 2010 & 5.8 & 34.1 & 60.1 & $\mathbf{7 7 2}$ \\
\hline Aug 2010 & 6.0 & 40.1 & 61.4 & $\mathbf{7 2 5}$ \\
\hline Sep 2010 & 6.1 & 46.2 & 62.7 & $\mathbf{7 3 5}$ \\
\hline Oct 2010 & 5.9 & 52.1 & 63.3 & $\mathbf{6 4 1}$ \\
\hline Nov 2010 & 5.4 & 57.5 & 63.5 & $\mathbf{5 8 6}$ \\
\hline Dec 2010 & 4.5 & 62.0 & 62.9 & $\mathbf{5 9 7}$ \\
\hline Jan 2011 & 4.7 & 4.7 & 55.4 & $\mathbf{7 0 5}$ \\
\hline Feb 2011 & 5.5 & 10.2 & 63.1 & $\mathbf{7 9 0 5}$ \\
\hline TOTAL & $\mathbf{6 2 . 5}$ & & & \\
\hline
\end{tabular}


From Table 3 it can be seen that the total freight for that period was $62.5 \mathrm{Mt}$. The year-todate column shows the cumulative freight after each month. The annualised monthly rate shows freight for one year at the given month of 2010 (for example, April 2009 to February 2010 equals $66.8 \mathrm{Mt}$ ). The last column shows the cumulative train shipments per month from March 2010 to February 2011. At that rate of transportation, it was predicted that the outcome for 2009 would be much lower than the figures for 2008, which stood at $76 \mathrm{Mt}$ (DMR, 2009:46). This can be attributed to the impact of the global economic slowdown in 2009 and other supply chain constraints.

\section{Richards Bay Coal Terminal (RBCT)}

The port of Richards Bay is situated $170 \mathrm{~km}$ north of Durban along the Indian Ocean coastline. It was opened in 1976 and commenced with an export capacity of 10 Mtpa. This capacity grew over the years and reached a capacity of 72 Mtpa on completion of eleven caissons by 2008 (Goussard, 2009:8).

RBCT is the largest single coal export terminal in the world, exporting more than $69 \mathrm{Mt}$ annually. The port's export handling capacity in 2009 was 76 Mt and reached 91 Mt in 2010 (Prevost, 2009:7). The port is owned by 11 coal mining companies with Anglo Coal, BHP Billiton, Xstrata, Exxaro and Sasol owning most of the shares (DMR, 2009:47). In September 2006, RBCT set a new world record by loading and exporting 409809 tonnes of coal within 24 hours. The port has also grown into a 24-hour operation with export capacity of 68 Mtpa in 2006 and reaching 91 Mtpa in 2010 (Prevost, 2009:7). The expansion of the port will cater for future coal export growth and will enable the servicing of emerging BEE coal miners which are presently allocated 4 Mt per annum (DMR, 2009:47).

With five berths and four ship loaders RBCT is linked by Transnet's $650 \mathrm{~km}$ rail line with the coalfields in Mpumalanga for export coal. At inception in 1976, the rail had trains with 50 wagons carrying 3742 tonnes of export coal and by 1996 the rail line had become a worldclass rail system and presently moves $2.5 \mathrm{~km}$-long trains with 200 wagons carrying up to 17000 tonnes of coal to the Richards Bay coal terminal. The terminal has a storage capacity of 6.7 Mt of coal that is serviced by six stacker reclaimers, two stackers and a reclaimer. The port also co-ordinates the arrival and departure of ships with the National Ports Authority and handles about 700 vessels per annum (Coal International, 2007:12). Table 4 shows the RBCT operating statistics for 2010/2011. 
Table 4: Richards Bay Coal Terminal (RBCT) operating statistics, 2010/2011 Source: South African Coal Report, (2011:8)

\begin{tabular}{|l|c|c|c|c|}
\hline Date & RBCT loadings (Mt) & YTD (Mt) & $\begin{array}{c}\text { Annualised rate } \\
\text { (Mtpa) }\end{array}$ & $\begin{array}{c}\text { Number of ships } \\
\text { loaded }\end{array}$ \\
\hline Mar 2010 & 5.7 & 15.5 & 62.5 & $\mathbf{6 3}$ \\
\hline Apr 2010 & 3.9 & 19.4 & 58.8 & $\mathbf{5 2}$ \\
\hline May 2010 & 4.6 & 24.0 & 57.7 & $\mathbf{5 2}$ \\
\hline Jun 2010 & 4.0 & 28.0 & 56.2 & $\mathbf{4 5}$ \\
\hline Jul 2010 & 5.9 & 33.9 & 58.2 & $\mathbf{7 0}$ \\
\hline Aug 2010 & 5.5 & 39.4 & 59.0 & $\mathbf{6 3}$ \\
\hline Sep 2010 & 5.4 & 44.8 & 59.6 & $\mathbf{6 4}$ \\
\hline Oct 2010 & 7.4 & 52.2 & 62.4 & $\mathbf{7 4}$ \\
\hline Nov 2010 & 5.2 & 57.4 & 62.4 & $\mathbf{5 9}$ \\
\hline Dec 2010 & 6.2 & 63.6 & 63.4 & $\mathbf{6 4}$ \\
\hline Jan 2011 & 4.4 & 4.4 & 51.6 & $\mathbf{4 5}$ \\
\hline Feb 2011 & 4.6 & 9.0 & 55.3 & $\mathbf{4 4}$ \\
\hline TOTAL & $\mathbf{5 5 . 5}$ & \multicolumn{3}{|c|}{} \\
\hline
\end{tabular}

Table 4 shows the monthly coal loading profile at the RBCT. Cumulative tonnes loaded in 12 months from March 2010 until February 2011 are shown in the second column. The third column is the annualised monthly total tonnage of coal loaded into the ship while the fourth column shows the monthly number of ships loaded at the RBCT terminal from March 2010 to February 2011 and the cumulative number of ships loaded during the same period.

\section{THE SOUTH AFRICAN COAL SUPPLY CHAIN MODEL}

Supply chain management entails an integrative and systems philosophy of managing the total flow of a distribution channel from suppliers to ultimate user (Van Weele, 2003:209). A typical supply chain comprises suppliers of raw materials, manufacturers, retailers and consumers (Bozarth \& Handfield, 2006:8; Lambert, 2006:1). The ultimate objectives of a supply chain are ensuring customer satisfaction, improving quality, reducing cost and improving services (Govil \& Proth, 2002:67). Key role-players in the South African coalmining industry supply chain include mining companies, government departments responsible for minerals and environmental affairs, domestic and export coal customers, rail logistics company Transnet, and the main coal export terminal RBCT. Figures 1 and 2 show the domestic and export supply chain coal model syndicating the downstream stages involved to the customers. 


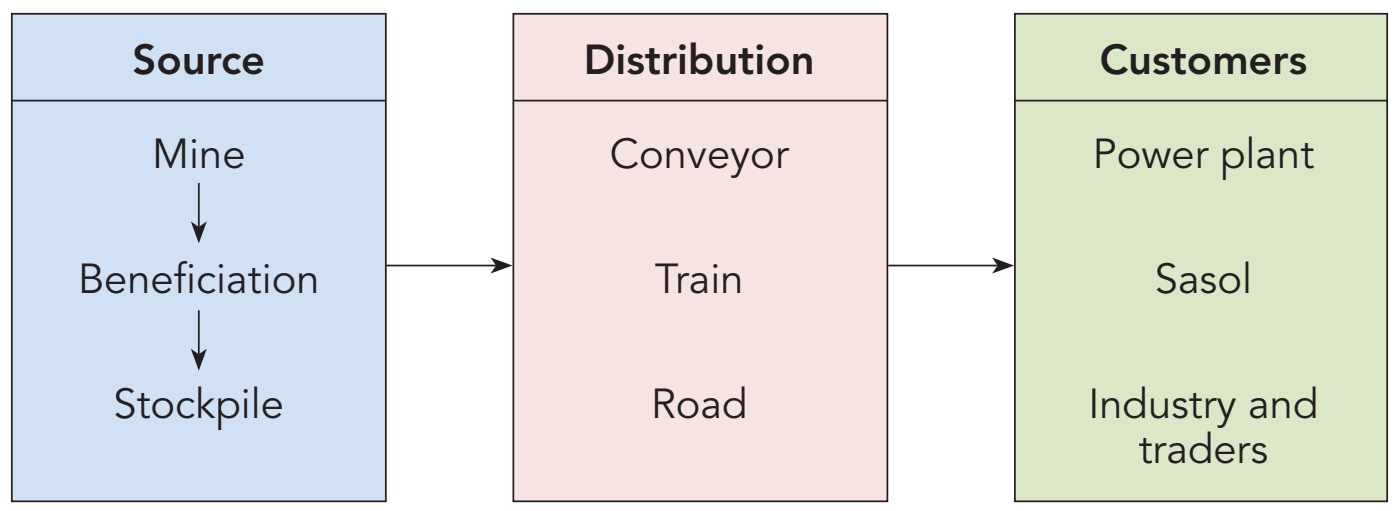

Figure 1: South African coal supply chain (Domestic)

Source: Own model

Figure 1 shows the South African domestic coal supply chain which has three main levels: coal mine (including beneficiation and stockpiling); transportation (conveyor, rail and road); and customers (power plants, Sasol, industry and traders). Most of South African coal customers are also the users (power stations, Sasol and industry). Only a very small volume of South African domestic coal is handled by traders. Figure 2 shows the South African export coal supply chain.

\begin{tabular}{|c|c|c|c|c|c|}
\hline Mine & $\begin{array}{c}\text { Coal } \\
\text { preparation } \\
\text { and } \\
\text { stockpiling }\end{array}$ & Train load & $\begin{array}{c}\text { Export } \\
\text { tterminal } \\
\text { (RBCT) }\end{array}$ & Ship load & $\begin{array}{c}\text { Import } \\
\text { terminal } \\
\text { (overseas) }\end{array}$ \\
& $\longrightarrow$ & & & & \\
\hline
\end{tabular}

Figure 2: South African export coal supply chain

Source: Own model

The supply chain stages begin at the mine/colliery, move to preparation and stockpiling, to loading the train, and then to the export terminal where the coal is then shipped to overseas customers.

\section{MAKING THE SA COAL MINING INDUSTRY SUPPLY CHAIN MORE EFFICIENT AND COLLABORATIVE}

\section{Inefficiencies within the coal mining supply chain}

A major current constraint in moving coal to markets, particularly export markets, is South Africa's ageing and inefficient rail infrastructure. Nearly all of South Africa's export coal is transported via rail from the central coal basin to Richards Bay on the east coast (Eberhard, 2011). 
The supply and quality of coal remain problematic. Only three of Eskom's power stations - Kriel, Matla and Matimba - are currently supplied entirely by conveyor systems from adjacent mines. Supplies to the Lethabo, Hendrina, Kendal, Duvha, Tutuka and Arnot power stations are done by a conveyer system and have to be supplemented by road deliveries of coal. The Camden power station is entirely supplied by road and Majuba is supplied by both road and rail (Eberhard, 2011). According to Rypstra (2011) it is vital for an industry that is dependent on its distribution network to become more equitable and cost-efficient in the road-versus-rail distribution. Deteriorating coal quality at Duvha, Matla and Tututka, in particular, have caused these power stations to operate well below their capacity, resulting in revenue losses.

The Waterberg field is $1050 \mathrm{~km}$ from the coast and does not yet have a dedicated coal rail link to Richards Bay. Currently, small amounts (less than $1 \mathrm{Mtpa}$ ) are railed from the Waterberg via the existing TFR network. The current rail capacity remains below 68 Mtpa, and actual performance has been even lower with some costly derailments. Shortages of locomotives, wagons and skills are also cited as other constraints (Eberhard, 2011).

The capacity of RBCT was increased from 72 Mtpa to 91 Mtpa in 2010. According to the South African Coal Report (2011:1) unless rail capacity is increased, RBCT will not reach the $91 \mathrm{Mtpa}$ capacity. Unfortunately, Transnet has been struggling to transport enough coal in recent years and has been plagued by derailments. The Chief Executive Officer of RBCT, Raymond Chirwa, is quoted as follows: 'It would be irresponsible for RBCT to expand when the other items of the value chain have not expanded. We can extend beyond 100 Mtpa but that depends on the performance of Transnet Freight Rail, which has not expanded its infrastructure to our 91 Mtpa capacity. At the moment there is a deficit in the rail' (Bishop, 2011).

\section{The idea of collaboration}

While the private sector is not happy about the state of the rail infrastructure, there a willingness and urgent wish on its part to engage with government to find solutions (Supplychainforesight, 2011:20). The private sector is willing to work with government to solve this complex problem of minimising inefficiencies and constraints within the coal mining supply chain. The ever-increasingly complex challenges facing society today require that the various interest groups come together to address such issues. A situation where two or more organisations come together to address a complex societal issue is broadly referred to in the literature as a collaboration (Gajda, 2004:66; Majumdar, Moynihan \& Pierce, 2009:55).

The idea of collaboration is underpinned by the assumption that by working together, scarce resources can be maximised and duplications minimised in order to achieve a common and shared vision which is otherwise not possible to achieve (Gajda, 2004:67). 
Furthermore, collaboration has potential to build social capital while developing trust and mutually supportive relationships with the various stakeholders (Majumdar, et al., 2009:56). For this to happen, Leach, Pelkey \& Sabatier (2002:651) argue that collaborations need to be periodically evaluated.

Collaborations of different kinds - between public agencies, community organisations and the private sector - have been a subject of interest for many researchers and policy makers (Shortell, Zukoski, Alexander, Bazolli, Conrad, Hasnain-Wynia, Sofaer, Chan, Casey \& Margolin, 2002; Lasker \& Weiss, 2003; Sabatier, 2005; Zahner, 2005). While most studies focused on collaborations between government and non-government agencies, not much has been written on collaborations between government agencies and between government and private sector businesses (Daley, 2008:479). Collaborations among businesses have been explored in the literature (Buckley \& Casson, 1988; Todeva \& Knoke, 2005). As discussed earlier, in the case of the export market, the coal mining supply chain includes mining companies which are all privately owned, TFR and the rail infrastructure which are government-owned, and the RBCT which is privately owned. Thus collaboration in this supply chain would be one between government and the private sector.

While the benefits of collaboration do not seem to be a subject of controversy in the literature, the definition thereof remains elusive and inconsistent. From the definition, it is not clear from what point an inter-organisational relationship becomes a collaborative one. Hence, some collaboration theorists contend that collaborative efforts fall across a continuum of low-to-high integration and that the level of integration is determined by the intensity of the relationship's process, structure and purpose (Gajda, 2004:68). Likewise, Todeva and Knoke (2005) posit that the level of collaboration among organisations is determined by increasing integration and increasing formalisation. Figure 3 illustrates the continuum of integration for collaborations.

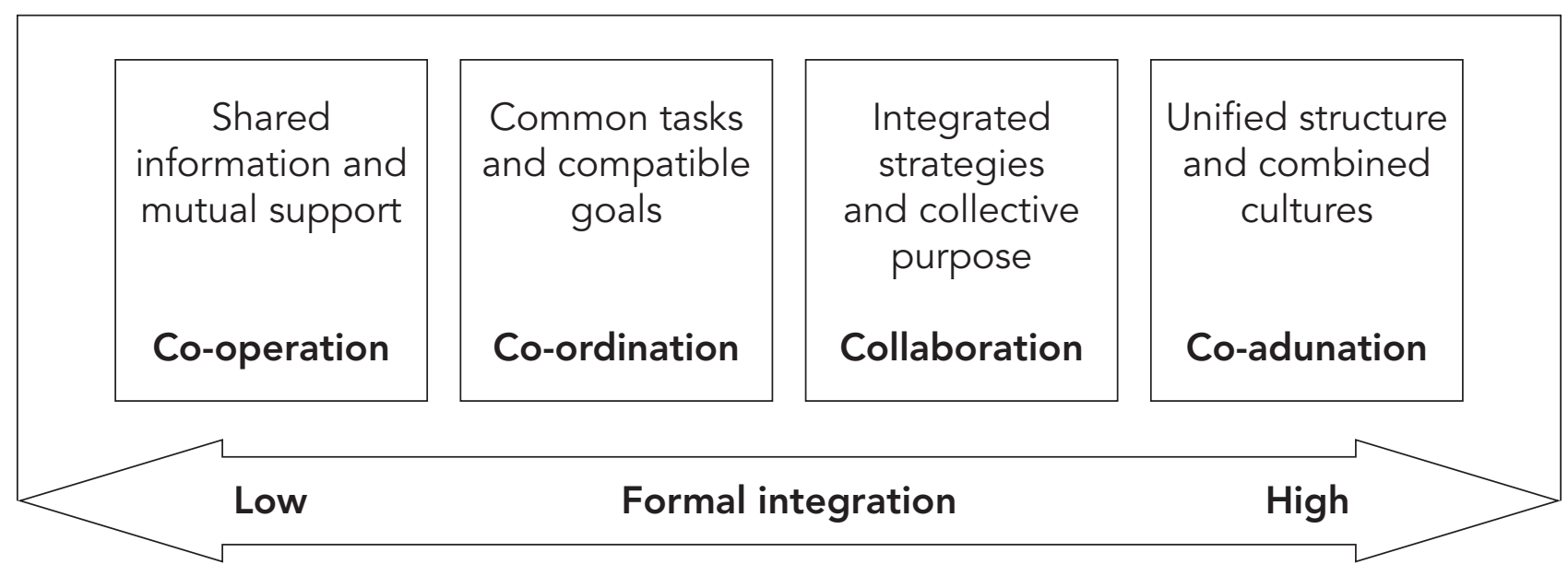

Figure 3: Defining strategic alliance across a continuum of integration Source: Gajda, 2004:69 
At its most basic form an inter-organisational relationship begins with co-operation whereby organisations share information that supports each other's outcomes. The relationship reaches co-ordination when organisations align activities or co-sponsor events or services that support mutually beneficial goals. The next level is collaboration, in which case individual entities give up some degree of independence in an effort to realise a shared goal. Collaboration is the most highly developed level of integration point on the continuum (Gadja, 2004:69).

Supply chains provide logical platforms for collaborations. Supply chain collaboration is defined as two or more independent firms jointly working to align their supply chain processes so as to create value to end customers and stakeholders with greater success than acting alone (Horvath, 2001:7). Collaborating firms share responsibilities and benefits by establishing a degree of co-operation with their upstream and downstream partners in order to create a competitive advantage (Simatupang, Wright \& Sridharan, 2004:57).

Collaboration is the means by which companies within the supply chain work together to attain mutual objectives through the sharing of ideas, information, knowledge, risks and rewards (Zacharia, Nix \& Lusch, 2009:101). The success of collaboration largely depends on technology. Members of the supply chain may either use their own systems or outsource them. The benefits accrued are across the board from raw material suppliers to customers. It brings down inventory, increases forecast accuracy and increases revenue to customers. Suppliers of materials benefit from reduced inventory, lower warehousing costs, reduced stock-outs and lower materials acquisition costs (Sadler, 2007:247). On the other hand, suppliers experience faster and more reliable deliveries, lower capital costs and lower freight costs. Value chain role-players realise all these benefits by participating in collaborative relationships (Cohen \& Roussel, 2005:140).

Effective collaboration is a source of competitive advantage which aims to improve customer service, profit generation, asset utilisation and cost reduction. The goal of collaboration should be realised within each entity (cross-functional) and between chain entities (crossenterprise). According to Kampstra, Ashayeri and Gattorna (2006:322), supply chain collaboration (SCC) has three loops namely the strategy loop, the change loop and the control loop:

- The strategy loop: choosing strategic partners, identifying supply chain strategy and aligning with corporate strategy

- The change loop: determining which entity should change and what should change

- The control loop: governing the transformational change, governing strategic objectives and allocating benefits and burdens. 
Supply chain collaboration should be an ongoing process in which all parties are interested in participating. In South Africa, there exists a need for such collaboration within the integrated supply chain of the coal mining industry. For such supply chain to be successful it would need to have the following features as suggested by Jain and Benyoucef (2008:469):

- strategies, technologies, people and systems

- environmental protection as the global ecosystem will always be strained by growing population and the emergence of new high-technology economies

- re-engineering (customisation, lean, agile, flexible, demand chain management and integrated supply chain scheduling issues for long supply chains).

The purpose of supply chain collaboration is to deal with constraints in order to improve the supply chain performance (Kampstra, et al., 2006:317). The model shown in Figure 4 proposes an integrated strategy for the development of the coal mining (ISDCM). The intent of the supply chain strategy is to reduce uncertainties and costs while satisfying the needs of customers. The strategy enables 'the integration of all the supply chain activities through the improved supply chain relationships in order to achieve a competitive advantage' ( $\mathrm{Nel}$ \& Badenhorst-Weiss, 2010:205). Figure 4 illustrates the proposed model for efficient and collaborative relationship within the South African coal mining industry.

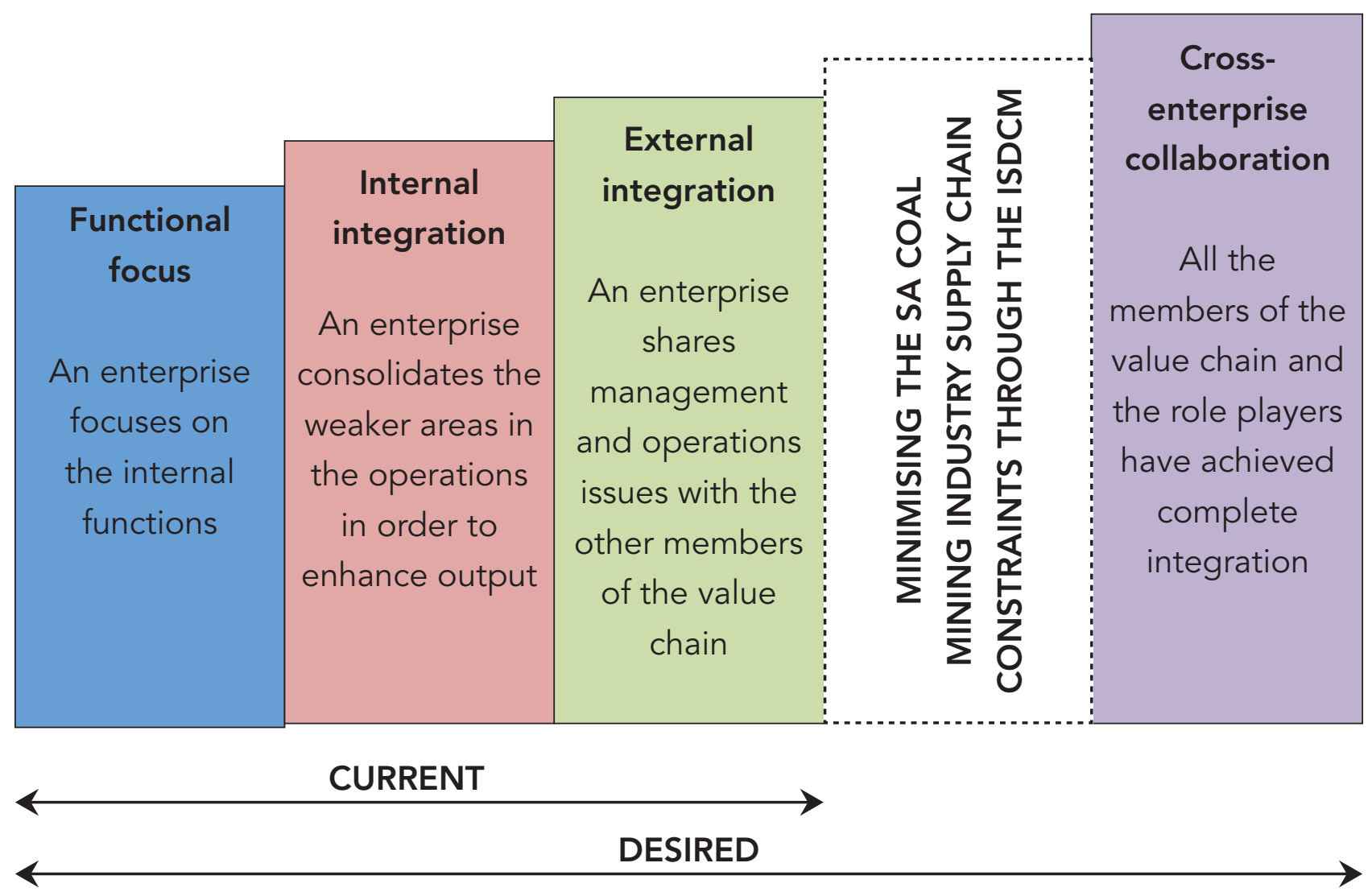

Figure 4: A model towards efficient cross-enterprise collaboration within the South African coal mining industry Source: Adapted from Super Group (2005, p.11) 
The model given in Figure 4 shows the current status of the South African coal mining industry and the desired aim to reach cross-enterprise integration. Under the prevailing situation the industry has stagnated at functional focus, internal integration and external integration. However, when the ISDCM is implemented, the industry is likely to achieve the desired level of cross-enterprise integration.

\section{Stage 1: Functional focus}

During this phase the entity focuses on the internal functions by department with emphasis on materials requirement planning (MRP) and manufacturing resource planning (MRP II).

\section{Stage 2: Internal integration}

During this stage the organisation realises the value of inter-departmental co-operation. Complete internal integration is accomplished by consolidating the weaker areas within operations in order to enhance output.

\section{Stage 3: External integration}

External integration is realised as the entity shares management and operations issues with the other members of the value chain, suppliers, distribution centres and logistics companies providing transportation. Co-operation is established through areas such as purchasing, transportation, marketing, product promotion, communication (use of information systems like Electronic Data Interchange [EDI] and Enterprise Resource Planning [ERP]) and other functions which increase profitability and value to the customer.

The coal supply chain begins to be constrained at this phase as the level of collaboration is not cohesive enough in the rail freight, which is fully government-owned through Transnet and the customers (mines are privately owned). Collaboration with the other major customer, Eskom, is also lacking due to policy issues as both are state-owned corporations with different operating mandates.

\section{Stage 4: Cross-enterprise collaboration}

Cross-enterprise collaboration happens when all the members of the value chain and the role-players have achieved complete integration. Communication is enhanced through electronic data interchange or other advanced information systems such as ERP. At this phase, orders, or any other supply chain problems, are easily traceable at any point in the value chain. Lambert (2006:357) highlights that for cross-enterprise collaboration to take place, high levels of trust must exist between supply chain partners since partners have to share relevant information and business processes.

In order to improve the performance of the entire supply chain, it is imperative that the supply chain partners identify drivers that determine performance of the supply chain. 
In this regard, Nel and Badenhorst-Weiss (2010:209) identify six supply chain drivers, namely: facilities, inventory, transportation, information, sourcing and pricing - all of which have an impact on the efficiency of the supply chain and its ability to respond to changing market needs. Figure 5 illustrates the interaction between the ISDCM, supply chain structure and supply chain drivers, and how they all impact on the efficiency and responsiveness of the SA coal mining supply chain.

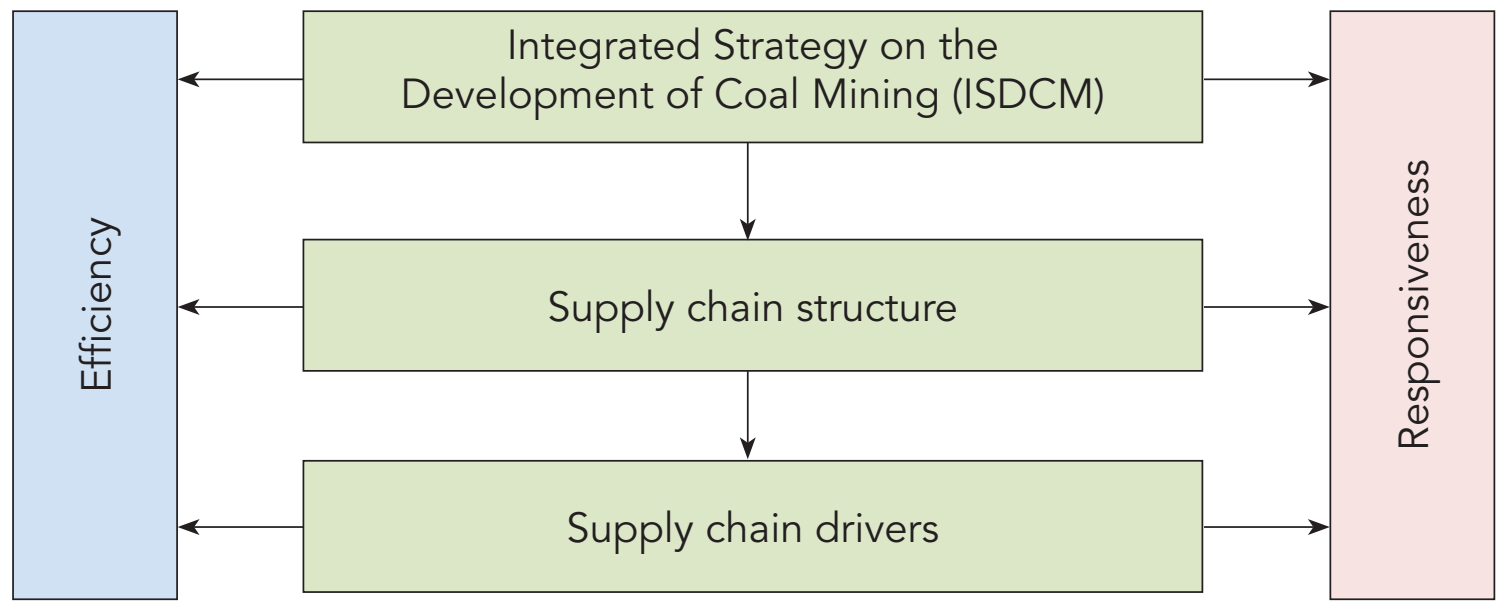

Figure 5: The relation of supply chain drivers towards supply chain strategy Source: Adapted from Nel and Badenhorst-Weiss (2010:210)

The ISDCM will need to be underpinned by efficiency and responsiveness to changing market needs. Key to the ISCDM will be the supply chain drivers, namely facilities, inventory, transportation, information, sourcing and pricing. The strategy will enable the industry to develop or make necessary improvements on the existing supply chain structure in line with the new strategy.

\section{CONCLUSION AND RECOMMENDATIONS}

Despite the increasing environmental challenges placed on the coal mining industry, the next few decades seem to still hold a bright future for this black rock. It is evident from the preceding discussion that for many more years to come the world will still use coal for power generation. More than $50 \%$ of coal produced in SA is consumed by Eskom for power generation while $24 \%$ is destined for the export market. The demand for coal on the local and export markets is on the increase due to the increased demand for electricity generation locally and the ever-increasing demand for coal by other countries, notably India. The increased demand for coal is likely to increase pressure on the industry supply chain.

The anticipated lack of re-investment by the main producers of coal and the lack of fresh investment by new investors should be a major concern for the future of the industry. The 
decline in coal shipments by Transnet from 2005 to date is also a cause for concern. However, individual players in the industry have started responding to some of the constraints they are facing. These include the Eskom Development Programme, Transnet's 'Quantum Leap Project' and 'Rail Expansion Programme', RBCT's Beyond 81 Mtpa Project' and the Department of Transport's 'National Freight Logistics Strategy'. To a large extent, the coal mining industry still operates on stages 2 (internal integration) and 3 (external integration) of the model presented in Figure 4.

The coal mining industry needs to move to stage 4 (cross-enterprise collaboration) of the proposed model. For this to happen, the industry requires an ISDCM. This strategy should ensure efficiencies along and responsiveness of the entire supply chain of the coal mining industry. Key elements of this strategy will include the facilities, transportation, information, sourcing, and pricing, among other things. As part of the formulation of the ISDCM, this article recommends an empirical study that determines the constraints facing the coal mining industry in South Africa.

In order to formulate and implement the ISDCM, a co-ordination committee which comprises all stakeholders in the coal mining industry has to be established. The co-ordination committee work would feed directly into the National Planning Commission. The National Planning Commission is best suited to deal with this strategy since it focuses on 'long term cross cutting issues such as food, energy and water security' (Republic of South Africa (RSA), 2009:4). While the ISDCM deals with the coal mining industry, it ultimately deals with energy issues, which are critical for the nation. Its membership would also include experts in energy, engineering, researchers, coal logistics, mining, rail/road/water infrastructures, environmental issues, commodity traders, economics, planning and finance, among others.

The establishment of the ISDCM co-ordination committee would be a milestone in streamlining some of the most critical national development issues. Government departments would speed up policy interpretation to open up the team's planning and processes. 


\section{REFERENCES}

Abbott, K., Apostolik, R., Goodman, G., Jenner, M., Labhart, G., Maragos, S., May, M., Sunderman, A. D., Parker, J., Stein, J., Wengler, J. \& Went, P. 2009. Foundations of Energy Risk Management: An overview of the energy sector and its physical and financial markets. Global Association of Risk Professionals (GARP). Hoboken, NJ: John Wiley.

Bishop, C. South African Transnet unable to expand with Richards Bay Coal Terminal. Accessed on 11/08/2011 at www.platts.com/RSSFeedDetailedNews/RSSFeed/coal/8730928.

BP. 2009. BP Statistical Review of World Energy. London: BP.

Bozarth, C.C. \& Handfield, R.B. 2006. Introduction to operations and supply management. Upper Saddle River, New Jersey: Pearson Prentice Hall.

Buckley, P. \& Casson, M. 1988. A theory of cooperation in international business. Management International Review, Special Issue. 19-38.

Chamber of Mines of South Africa. 2009. Annual Report.

Chadwick, J. 1994. World Coal. Mining Magazine. September Issue. London. Mining Publication.

Coal International. 2007. International energy outlook. [Online]. Available at: $<$ www.eia.doe.gov/ieo/coal.html>. Accessed October 2008.

Cohen, S. \& Roussel, J. 2005. Strategic Supply Chain Management. New York: McGraw-Hill.

CSIR. 2006. Third Annual State of Logistics Survey. Pretoria: CSIR.

Daley, D.M. 2008. Interdisciplinary problems and agency boundaries: Exploring effective cross-agency collaboration. Journal of Public Administration Research and Theory. 19:477-93.

Department of Minerals and Energy. 2007. South Africa's Mineral Industry (SAMI). Pretoria.

Department of Mineral Resources (DMR). 2009. Growth Prospects of South Africa's Coal Exports and the effects on the Black Economic Empowerment Companies. Pretoria.

Department of Transport. 2005. National Freight Logistics Strategy. Pretoria. 
Eberhard, A. 2011. The future of South African coal: Market, investment, and policy challenges. Working Paper No. 100. Programme on Energy and Sustainable Development. Encina Hall East, Room E415 Stanford University Stanford, CA 94305-6055.

Eskom 2009. Annual Report.

Furter, L. 2005. Time to revolutionise logistics systems. Multimodal: supply chain management. TWA. April.

Gajda, R. 2004. Utilising collaboration theory to evaluate strategic alliances. American Journal of Evaluation. 25(1):65-77.

Goussard, L. 2009. New berth 306 expands capacity of RBCT. Civil Engineering, May, p8.

Govil, M. \& Proth, J.M. 2002. Supply Chain Design and Management. San Diego (CA): Academic Press.

Hartnady, C.J.H. 2010. South Africa's diminishing coal reserves. South African Journal of Science. 106 (9/10). www.sajc.co.za. Accessed online 25/5/2011.

Hartnady, C.J.H. 2011. Estimates of SA coal reserves. Inside Mining. 2:22-28.

Horvath, L. 2001. Collaboration: the key to value creation in supply chain management. Supply Chain Management. 6(5):205-207.

Jain, V. \& Benyoucef, L. 2008. Managing long supply chain networks: Some emerging issues and challenges. Journal of Manufacturing Technology Management. 19(4):469-96.

Kampstra, R.P., Ashayeri, J. Gattorna, J.L. 2006. Realities of supply chain collaboration. The International Journal of Logistics Management. 17(3):312-30.

Lambert, D.M. 2006. Supply chain management. In Lambert, D.M. (ed). Supply chain management: process, partnerships, performance. 1-24. Florida: Supply Chain Management Institute.

Lasker, R. \& Weiss, E. 2003. Broadening participation in community problem solving: A multidisciplinary model to support collaborative practice and research. Journal of Urban Health. 80(1):495-507. 
Leach, W.D., Pelkey, N.W. \& Sabatier, P.A. 2002. Stakeholder partnerships as collaborative policymaking: Evaluation criteria applied to watershed management in California and Washington. Journal of Policy Analysis and Management. 21(4):645-70.

Lok, G. 2009. Demand vs energy supply. Inside Mining. November/December.

Majumdar, S.R., Moynihan, C. \& Pierce, J. 2009. Public collaboration in transportation: A case study. Public Works Management \& Policy. 14(1):55-80.

Mining Weekly. 2010. A brief look at SA's coal-mining industry. 03 September. Accessed on 17/08/2011 at www.miningweekly.com/print-version/.

Molteno, C. 2008. How best to meet South Africa's future energy requirements. Transactions of the Royal Society of South Africa. 63(2):189-91.

National Energy Regulator of South Africa (Nersa). 2008. Inquiry into the national electricity supply shortage and load shedding. 12 May.

Nel, J.D. \& Badenhorst-Weiss, J.A. 2010. Supply chain design: some critical questions. Journal of Transport and Supply Chain Management. November, 198-223.

Nyanjowa, W. 2009. South Africa's coal mining industry's comeback rides on Waterberg coal basin. Coal International. November/December, 8.

Prevost, X. 2009. Underground coal gasification. Inside Mining. September, 7-9.

Republic of South Africa (RSA). 2009. Green Paper: National Strategic Planning: The Presidency.

Rypstra. 2011. How SA risk losing its Africa gateway status. June. Accessed on 04/08/2011 at www.focusontransport.co.za/features.

Sabatier, P.A. 2005. Swimming upstream: collaborative approaches to watershed management. Cambridge, MA: MIT Press.

Sadler, I. 2007. Logistics and supply chain integration: Business and economics. London: SAGE.

Shortell, S.M., Zukoski, A.P., Alexander, J.A., Bazolli, G.J., Conrad, D.A., Hasnain-Wynia, R., Sofaer, S., Chan, B.Y., Casey, E. \& Margolin, F.S. 2002. Evaluating partnerships for community health improvement: Tracking the footprints. Journal of Health Politics Policy and Law. 27:49-91. 
Simatupang, T.M., Wright, A.C. \& Sridharan, R. 2004. Applying the theory of constraints to supply chain collaborations. Supply Chain Management, An International Journal. 9(1):57-70.

Smuts, W. 2008. Why coal is once again king. Inside Mining. September, pp.33-37.

Smuts, W. 2010. The role of coal: Will we make it to 2050? Inside Mining. September, pp.16-21.

South African Coal Report. 2011. Coal focuses on Maputo option. Issue 2026, March. (www. coalportal.com).

Super Group. 2005. MRP, MRRII\% The whole supply chain thing. An Overview. 19 October.

Supplychainforesight. 2011. Evolving Strategies: Competitive supply chains in emerging economies. Barloworld Logistics.

Todeva, E. \& Knoke, D. 2005. Strategic alliances and models of collaboration. Management Decision. 43(1):123-48.

Transnet. 2008. Annual Report.

Transnet. 2009. Annual Report.

Van Dyk, E., Ittmann, H., Marais,M., Meyer, I \& Maspero,E. 2008. The state of logistics: Research priorities for sustained improvement. Journal of Transport and Supply Chain Management. November, 93-106.

Van Weele, A.J. 2003. 3rd ed. Purchasing and Supply Chain Management (analysis, planning and practice). London: Thomas Learning.

Venables, M. 2008. Power coal: Back to black. Engineering \& Technology. November, 46-51.

Wood, L. 2010. Research and Markets: Coal-mining in South Africa 2009. Accessed online http://www.researchandmarkets.com/research/abafcb/coalmining on 25/5/2011.

Zacharia, Z.G., Nix, N.W. \& Lusch, R.F. 2009. An analysis of supply chain collaborations and their effects on performance outcome. Journal of Business Logistics. 30(2):101-23.

Zahner, S.J. 2005. Local public health partnerships. Public Health Reports, 120:76-83. 
Table of acronyms

\begin{tabular}{|l|l|}
\hline BEE & Black Economic Empowerment \\
\hline DMR & Department of Mineral Resources \\
\hline EDI & Electronic Data Interchange \\
\hline ERP & Enterprise Resource Planning \\
\hline GDP & Gross Domestic Product \\
\hline ISDCM & Integrated Strategy for the Development of the Coal Mining \\
\hline MRP & Materials Requirement Planning \\
\hline MRP I & Manufacturing Resource Planning \\
\hline Mt & million tonnes \\
\hline Mtpa & million tonnes per annum \\
\hline Nersa & National Energy Regulator of South Africa \\
\hline RBCT & Richards Bay Coal Terminal \\
\hline SCC & Supply Chain Collaboration \\
\hline TFR & Transnet Freight Rail \\
\hline YTD & Year to Date \\
\hline
\end{tabular}

